\title{
Community Engagement: Small things but have a big impact on Empowerment
}

\author{
Jumiati $^{1}$, Hidayatul Fajri ${ }^{2}$, Boni Saputra ${ }^{3}$ \\ \{jumiatifis@ fis.unp.ac.id ${ }^{1}$, hidayatulfajri@ fis.unp.ac.id ${ }^{2}$, bonisaputra@ fis.unp.ac.id ${ }^{3}$ \} \\ Department of Public Administration, Universitas Negeri Padang, Padang, Indonesia ${ }^{1,2,3}$
}

\begin{abstract}
In the latest empowerment studies, community engagement is considered to be an important factor in the success of empowerment programs. Therefore, this study aims to analyze the community engagement that occurs in the fishermen empowerment program in Carocok Anau Village. This study uses a qualitative method with a case study approach. The research was conducted by observation and in-depth interviews with fishermen. The results showed that engagement did not occur due to several factors, namely: failure of social integration, distrust among communities, and deep social class differences between communities.
\end{abstract}

Keywords: Community Engagement, Empowerment Program, Fisherman

\section{Introduction}

Many empowerment programs carried out by the government target fishermen groups as an effort to increase their welfare. Some of these efforts aim to diversify the livelihoods of fishermen, such as the PEMP program (Coastal Community Empowerment Program) which has been initiated since 2000 . The program hopes that fishermen will no longer depend on fishing in the high seas but can be assisted by the results of this program.

However, most of these empowerment programs are top-down or government-centric. So that when the program is implemented, it does not get support from the target group. Several reasons, such as the incompatibility of the program with group needs, asymmetrical knowledge between government and groups, and the expected results make empowerment programs not work and ultimately become "wild-goose".

One of the recent studies or practices in empowering marginalized groups is engagement. This approach is considered as a response to the empowerment approach that tends to make marginalized groups an object, passive, and without initiative. Whereas the purpose of empowerment is to restore the power and ability of the target group to be independent. But unfortunately, empowerment, which is often in the form of top-down programs, does not provide space for independence for the group. This is what causes many empowerment activities to fail.

Several previous studies have explained the importance of community engagement in empowerment activities. Community engagement can simply be interpreted as how the community builds continuous and mutually beneficial reciprocal relationships [1]. Here it really 
requires formal and informal communication that can build mutual understanding and common perceptions. The reasons include giving back the authority to the target group for decision making, fostering group initiative, utilizing social capital in the group, and group social acceptance of the program. The research was conducted in Carocok Anau Village, Pesisir Selatan Regency where the majority of the population is fishermen. However, the empowerment programs implemented there have relatively failed to achieve their goals. Several previous studies have explained that the failure of empowerment in Carocok Anau Village is a result of governance and social capital [2], [3]. However, the failure to empower fishermen tries to explore further by using community engagement as a unit of analysis.

\section{Methodology}

Our study uses a qualitative research method with a case study approach [4]. The case study approach was chosen because it can analyze complex social phenomena and is also able to build a relationship between practical and theoretical abstraction [5], [6]. Besides, case studies also provide flexibility in the space for seeing new variables found during field data collection [7]. The location of this research is Carocok Anau Village with the object of research being the fishing communities along the coast of the village. The research was conducted from June to September 2019 and continued from April to July 2020. Data collection was carried out by; observation, document review, and interview.

The interview technique used in this research is in-depth semi-structured interviews by identifying individuals or actors who fall into the categories that have been assigned as informants [8]. However, informants can develop beyond what is determined if some individuals or actors are considered to have information that is relevant to the research. The informants in this study were: Head of Aquaculture Fishermen Groups in Carocok Anau Village, Carocok Anau Village Fishermen, and Carocok Anau Village Communities.

Meanwhile, semi-structured interviews were chosen because they are an appropriate way to gather information from an individual perspective, which focuses on experiences, beliefs, and perceptions. Interview topics include reasons for involvement in the empowerment of fishing communities, perceptions of empowerment, their perceptions of the community, the ideas they come up with, and their experiences in empowerment activities. The data validation technique used in this study was the source triangulation technique.

The data analysis technique that we use uses the stages of data analysis developed by Sutton and Austin (2015), namely, 1) Interpreting data 2) Transcribing and checking 3) Reading between the lines, 4) Coding, and 5) Theming. After that, the final work is to synthesize research findings to represent, as faithfully as possible, the meaning that participants ascribe to their life experiences. This synthesis is the aim of the final stage of qualitative research [9]. 


\section{Finding And Discussion}

\subsection{Condition of Fishermen in Carocok Anau Village}

Carocok Anau Village has a very good sea coast to serve as a marine business. The position of this village is protected by bays and small islands so that it becomes a safe dock for ships to lean on. This condition is also advantageous to be used as a place for fish farming because the ocean currents are not too strong. However, that is only a geographical advantage. The condition of the fishermen in Carocok Anau Village is still far from prosperous, except for some who are businessmen, namely fishermen who own medium and large vessels.

The fishermen in Carocok Anau Village can be categorized into 3 (three) groups, namely "Catch-Fishermen" (Nelayan Tangkap), Fishing road-Fishermen (Nelayan Pancing), and Aquaculture Fishermen (Nelayan Budidaya). Catch-fishermen are fishermen who carry out fishing activities off the coast, usually, the distance covered depends on the ship/boat he owns. Although only a few can sail to the Exclusive Economic Zone (EEZ) which is more than 100 miles offshore. Most of the catch-fishermen in Carocok Anau Village are only able to go to sea a few kilometers from offshore. This is due to the limited fishing gear they have.

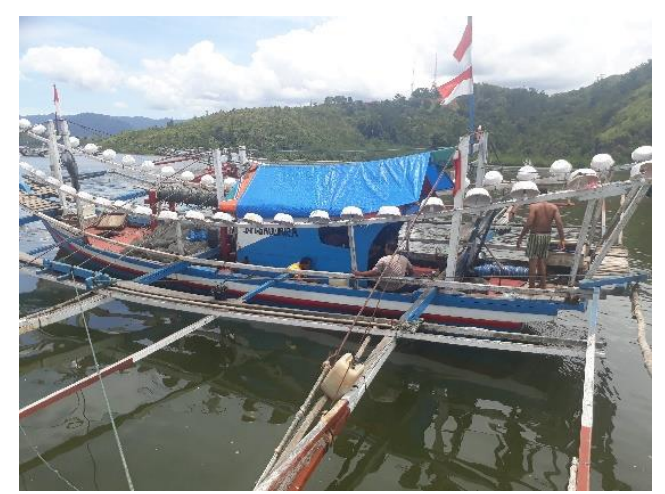

Fig 2. Catch-Fishermen in Carocok Anau Village

Catch-fishermen in Carocok Anau Village can be further divided into boat owner fishermen and boat workers. Boat owner fishermen consist of small boat owner fishermen and small boat owner fishermen. Small boat fishermen are fishermen who have fishing gear in the form of boats or boats with engines below $30 \mathrm{GT}$. Meanwhile, labor fishermen are fishermen who are crew members of the ship and do not own a boat. As a rule, labor fishermen use fishing gear in the form of "Bagan", so the labor fishermen work more permanently than labor fishermen who work in other fishing gear which tend to be odd jobs.

The types of fishing gear in Nagari Carocok Anau also vary, namely 70 units of "gill nets", 67 units of "Bagan", 30 units of "edge seine", 35 units of "trolling line", and 35 units of "payang" (Carocok village profile Anau, 2017). Whereas the waters of Carocok Anau Village have a fairly large potential, namely around 8,500 tons/year of demersal fish and 600 tons/year of pelagic fish. But in 2017 the value of fish production was only around 1,467 tons with an estimated sales price of around 31 billion rupiahs. 
The second type of fisherman is fishing-rods. This fisherman is only seasonal and odd. Even so, in certain seasons there are quite a lot of fishing rod fishermen. Usually, they only use small boats with robin engines powered by 5 GT and go alone or in pairs. The response distance is only limited to the bay of the waters of Carocok Anau Village.

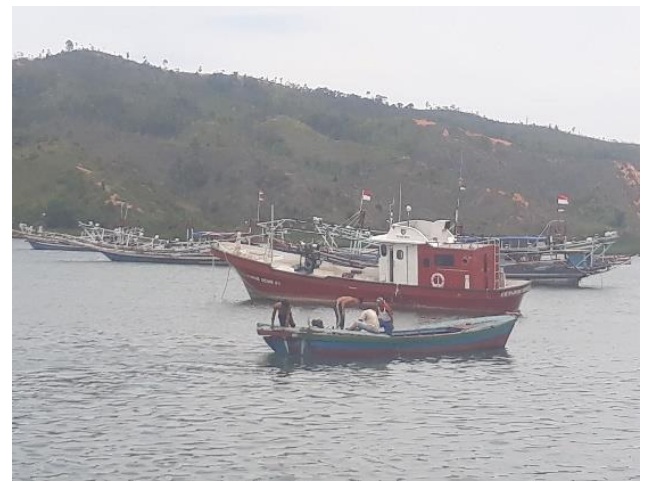

Fig 3. Fishing Rods-fishermen in Carocok Anau Village

The third fisherman is an aquaculture-fisherman. Most of the aquaculture fishermen also work as catch fishermen and sometimes fishing rods. Initially, seawater cultivation in Carocok Anau Village was aimed at diversifying fishermen's income so that they do not depend on fishery products.

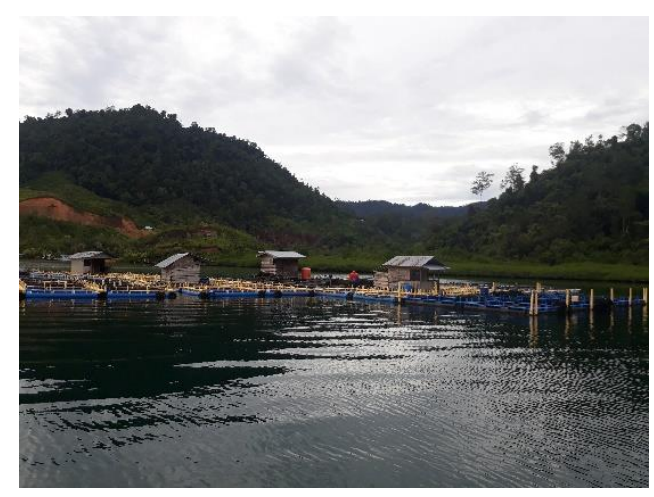

Fig 4. Aquaculture Fisherman in Carocok Anau Village

Aquaculture in Carocok Anau Village began in 2012 with the provision of 6 aquatics (floating net cages) with a total of 10 cages financed through the Pesisir Selatan Regency Regional Budget. The type of fish that is cultivated is grouper because it is considered to have high economic value. The management is then carried out by 8 (eight) groups of fishermen. The following year, the fishermen in Carocok Anau Village received assistance again, this time from the Ministry of Fisheries and Maritime Affairs through the 2012 State Budget. And lastly, assistance in 2013 from the Fisheries and Maritime Affairs Office of Pesisir Selatan Regency. So that in 2014 the number of Aquatec cages in Carocok Anau Village was 50 cages with 500 holes. 


\subsection{Empowerment of Fisherman in Carocok Anau Village: An Overiew}

One of the empowerment programs in Carocok Anau Village is fish farming. Fish farming in Carocok Anau Village started in 2012 with the provision of 6 aquatics (floating net cages) with a total of 10 cage holes. The program is financed through the Pesisir Selatana Regency Regional Expenditure Budget. The type of fish that is cultivated is grouper because it is considered to have high economic value. The management is then carried out by 8 (eight) groups of fishermen. The following year the fishermen in Carocok Anau village received assistance again, this time from the ministry of fisheries and maritime affairs. And the last is assistance in 2013 from the Department of Fisheries and Marine Affairs. So that in 2014 the total number of Aquatec cages in Carocok Anau Village was 50 with 500 holes.

At first, fishermen in Carocok Anau Village were very enthusiastic about the empowerment program provided by the Pesisir Selatan Fisheries and Marine Service. The hope of fishermen, this empowerment will be able to increase their income. But in the first harvest, the results obtained were far from expected. Fishers are losing money, and some decide to leave the cultivation group. Although some continued. However, in the following year, the fishermen of Carocok Anau Village lost money again. Their harvest failed a second time. This then made almost all fishermen resign from empowerment activities. So that in the future, the existing aquatic cages are handed over to fishermen who still want to continue the grouper cultivation business.

"It started around 2011 for floating net cages. Many of the people assisted by the fisheries service did not develop. The real problem is not from the community itself, the community is even more enthusiastic about supporting the economy. But the problem purchasing power is low. Seedlings are sold to the public at a high price and after harvest, fish are bought at a price below the market standard for fish, causing the community to suffer losses. That is what makes the community discouraged and dies from the floating net cage business. "

(Interview with Head of Cultivation Fishermen of Carocok Anau Village)

The cultivation failure that occurred in Carocok Anau Village for some fishermen was the failure of the marketing process. Even so, it could not provide a thorough analysis to find out the answers to their failures. Although the indications from our research show that the available market is a monopsony market, where there is only one buyer who monopolizes, namely PT Dempo. However, PT Dempo's fish collection point before export is not far from Carocok Anau Village. The price purchased is also not below the domestic market price. Besides, it can also be compared to grouper cultivation in South Painan Village which can run well even though it has the same market. Thus, the reasons given by the fishermen in Carocok Anau Village cannot be completely accepted, that the failure is more caused by the existence of the market (see previous studies in 2, and 3). Therefore, at the next point, we will see that the cause of failure in empowering fishers in Carocok Anau Village is more about the failure of engagement from the community, especially fishers so that they fail to take advantage of existing empowerment programs. 


\subsection{Failure of Community Engagement in Empowerment}

From the research we conducted, there were three answers regarding the causes of the failure of Community Engagement in empowerment which ultimately failed the empowerment of fishermen in Carocok Anau Village. These three things are 1) Non-fluid social integration, 2) Lack of trust among community members, 3) Differences in social class among fishermen.

Non-Fluid Social Integration. The people of Carocok Anau Village are indigenous people who have long-rooted and inhabited the area. As a society rooted in social values. Not only customary values but also values in building social integration. Unfortunately, in such (traditional) societies they see changes in existing values as a threat. Including changes in production patterns. People have more faith in their old beliefs in production. Thus, when the empowerment program (delivered by the government) collides with their beliefs (eg shipshape, shipbuilding materials, ship size, fishing gear, including changes in production activities from "capturing" to "cultivating") they are less likely to be involved. do refusal.

Social integration has almost stopped and frozen into a culture that is no longer discussed by society. People tend to accept the truth of their culture from generation to generation. Belief in values that have been trusted from generation to generation is certainly not something to blame. However, space for society to return to "competence" in seeing existing values is closed. This is because the community will immediately clash with existing and trusted values. In this condition, for the people of Carocok Anau Village, values are no longer a formal affair but something that must be obeyed and emphasized. For engagement to take place, the community must be dynamic in responding to changes so that dialogue can lead to social integration in society.

Lack of trust among community members. Our research results show that the trust of the community, especially fishermen in Carocok Anau Village, is very low. Mutual distrust can be seen from the interactions that exist among community members. For example, when we asked some questions to the community or "labor fishermen" about their views on other community members and / fishermen or their perceptions of the existing empowerment program. The answers we got were answers that showed their distrust of certain groups, especially community elites or fishermen with large capital. They also accuse that the empowerment program provided by the government is only being used by these groups. Likewise, when we ask the same questions to elites and fishermen with large capital, they often accuse "labor fishermen" of being lazy, wasteful, and even stupid.

"That's the problem. We have to get help. Sorry sir, but indeed (the empowerment program) has many obstacles, sir. The point is not right on target. "

(Interview with one of the labor fishermen in Carocok Anau Village)

The a sharp difference in social class among the fishermen. Fishers in Carocok Anau Village can be divided into large boat owners (over $30 \mathrm{GT}$ ), medium boat owners (10 GT to <30 GT), small boat owners $(<10 \mathrm{GT})$ fishermen, and labor fishermen. This social class difference often creates hidden conflicts between them (although it never ends in social conflict).

The conflict was caused by business competition (among ship owners) in sharing the catch (between ship owners and workers). Although the fishermen in Carocok Anau Village already have a percentage that regulates the distribution of their catch, usually some things cause conflict between them. This caused suspicion among fishermen to be very high. Their failure to build this trust has an impact on their desire to be involved in existing empowerment programs. 
Even though community involvement has benefits for the success of the empowerment program because with community involvement it will be more inclusive and able to reduce the dominance of the instrument [10], the process (empowerment) becomes more interactive and dynamic [11], can function in the improvement of stakeholder engagement [12], and also reduce local conflict and opposition [13]-[15]. This in turn makes the empowerment program work and able to achieve its intended goals.

\section{Conclusion}

This research shows that engagement cannot just happen in the community in supporting the implementation of empowerment programs. This is because the community is not in a vacuum that can be formed according to the wishes of the government (it can be seen from the empowerment programs carried out by the government that often do not involve the community in determining what to do). So the first challenge for the government to realize engagement from the community before delivering the program is to understand the dynamics that exist in the community. Therefore, the government should revise the top-down approach they often use in delivering empowerment programs. An approach that prioritizes Community Engagement is something that should be prioritized by the government.

\section{References:}

[1] H. Fajri, P. Nurhabibi, B. Saputra, and P. Yuanjaya, "Community Engagement in a Social Movement: A Case of Geothermal Energy Development in Gunung Talang - Bukit Kili area," in IOP Conference Series: Earth and Environmental Science, 2020, vol. 448, no. 1.

[2] K. D. Maani, A. Firnaldi, and H. Fajri, "Fisherman Empowerment and Poverty In Pesisir Selatan Regency," in International Conference on Disaster Management (ICDM 2018), 2018.

[3] J. Jumiati and H. Fajri, "Modal Sosial: Seberapa Penting di dalam Keberhasilan Pemberdayaan Nelayan.," J. Teor. Dan Ris. Adm. Publik, vol. 2, no. 2, pp. 70-79, 2018.

[4] R. K. Yin, Disain dan Metode. Terjemahan M. Djauzi Mudjakir. Jakarta: PT Raja Grafindo Persada, 2003.

[5] A. Strauss and J. Corbin, Dasar-Dasar Penelitian Kualitatif. Yogyakarta: Pustaka Pelajar, 2007.

[6] C. J W, Research Design Pendekatan Kualitatif, Kuantitatif, dan Mixed. Yogyakarya: PT Pustaka Pelajar, 2010.

[7] R. Stake, Qualitative Case Study (3rd Ed). Sage: Thousand Oaks.

[8] G. Guest, E. Namey, and M. Mitchell, “Collecting Qualitative Data: a Field Manual for Applied Research,” 2013.

[9] J. Sutton and Z. Austin, "Qualitative Research: Data Collection, Analysis, and Management," C J P H, vol. 68, no. 3, 2015.

[10] M. Aitken, C. Haggett, and D. Rudolph, "Practices And Rationales of Community 
Engagement with Wind Farms: Awareness Raising, Consultation, Empowerment," $J$. Plan. Theory Pract., vol. 12, no. 4, pp. 557-576, 2016.

[11] S. Sonali and P. S. Sangle, "Stakeholder Engagement As A Dynamic Capability," J. Bus. Strateg. Dev., vol. 3, no. 2, 2020.

[12] A. Boaz, S. Hanney, R. Borst, and E. Al., "How To Engage Stakeholders In Research: Design Principles To Support Improvement. Health Res Policy," vol. 16, no. 60, 2018.

[13] S. Fast et al., "Lessons Learned From Ontario Wind Energy Disputes," Energy, vol. 1, 2016.

[14] T. Howard, "Olive Branches and Idiot's Guides: Frameworks for Community Engagement In Australian Wind Farm Development.," Energy Policy, vol. 78, pp. 137-147, 2015.

[15] K. Soma and C. Haggett, "Enhancing Social Acceptance in Marine Governance in Europe. Ocean Coast," Manag, vol. 117, pp. 61-69, 2015. 